\title{
WOMEN'S ROLES AND THE GREAT WORLD TRANSFORMATION
}

John Platt

The constructive worldwide processes of reform that have brought about, among other things, a reversal in attitudes towards birth control, sex, women's rights, marriage, and the family are competing with the disasters of famine, war, and economic collapse as the old structures break down under new global problems. If we are to survive, thousands of problems must be solved and our efforts "orchestrated" so as to fit together, at every level from personal awareness to global management. Women must identify the many areas of special concern to them, where their new analyses and reform efforts are needed to reverse the false goals and practices of centuries of male-dominated societies. One example is the crucial need for new analyses and design efforts for improved family structures.

THIS has been a century of almost continuous change in the technical and economic factors pressing for new roles and new rights for women all over the world. These changes include the mechanisation of agriculture and the move to the cities and suburbs, the impact of the automobile on family mobility, the women's suffrage movement, the role of women in wartime industry, the effect of automatic dishwashers and washing machines on household servants, the effect of television on the family, and the effect of oral contraceptives and new sex information. But there have been two periods when our consciousness has changed particularly fast on women's roles, women's rights, and the related questions of sex, birth control, marriage, and the family. The first was the 1920 s, and the second was the last decade; changes are still going on very rapidly and spreading around the world.

It is not generally realised how radical the new attitudes of the 1920s wereon the size of families and the independence of young people from their parents

Dr Platt is Associate Director, Mental Health Research Institute, University of Michigan, USA. A version of this article was presented to the Conference on "New Research on Women II", Center for Continuing Education of Women, University of Michigan, 19 March, 1975; and published in Dorothy McGuigan, ed, New Research on Women and Sex Roles (University of Michigan Center for Continuing Education of Women, 1975). 
and grandparents. For the great majority of human history since the ape men or the cave men, human beings have probably lived in troops, tribes, or extended families, whether they were nomadic or sedentary. Versailles had a thousand residents, and the smallest cottage often contained three generations, as Margaret Mead has emphasised; while a Polish or Russian farmhouse might have 20 people or more sharing a single chimney. Those 10- to 14-room Victorian houses in Chicago or Ann Arbor often had grandparents, aunts, maids, roomers, and a dozen children under one roof.

But the young people of the 1920s wanted to break away from the Victorian morality and rule of their grandparents, and to be modern and scientific about independence, sex, and the family. They took jobs in the big city, married without their parents' permission, and took a small apartment or a suburban bungalow where they could bring up one or two children far away from their mothers-in-law. The flapper era flaunted new freedoms, new jazz, more sexual dances, new skirt lengths, new hair lengths, joy-riding, illicit drugs like alcohol, new sexual freedom, and trial marriage. It is remarkable that the areas of culture change and consciousness change of the youth of the 1920 s should have so paralleled those of their grandchildren in the late $1960 \mathrm{~s}$.

\section{Mechanisms of change}

Nevertheless, for all the forerunners, we seem to be in a new situation today. Many changes of consciousness and of social structure are coming to birth that are more profound, more worldwide, and more permanent than anything that has gone before. Many of these changes are the direct or secondary result of the great technological changes after the Second World War. New nuclear power, missiles, and satellite television shrank the planet and forced us to realise the need for coexistence, ecological conservation, and a limitation to growth. New agriculture, medicines, and contraceptives made population planning both necessary and possible. Mass higher education, supermarkets, household appliances, and the shrinking family, along with the switch from manual labour to the services and communications industries, have made it easier to get out of housewifery into careers.

The role of television in correcting old injustices and speeding up social change is also greater than is generally realised. It is commonly supposed to press us toward a uniform style of life, as passive spectators. But for a small fraction of concerned citizens, television is instead an activating and differentiating force. On any controversial topic, it produces simultaneous outrage and protests in a hundred cities. People identify with the leaders or points of view that they see on the box; and ecology movements, or ethnic movements, or women's movements, spring up everywhere at the same time without any central committee to tell them what to do. Their political power is sudden and remarkable, and it is interesting to see how many of the old-fashioned managers and manipulators, the "best and the brightest" in government and industrypro-centralisation, pro-Vietnam-war, pro-supersonic-transport, pro-auto, progrowth, pro-pollution, pro-male, pro-natalist-have gone down again and again in the last 10 years before the power of these movements of consciousness.

It is instructive to follow the detailed process by which these movements are 
able to reverse the laws or attitudes of decades or centuries past. A classic example is the ecology movement, which might be said to have begun with Rachel Carson's book, Silent Spring, ${ }^{1}$ in 1962.

This was a "catalytic analysis" of the problem, which put the factors together in a persuasive way that many could follow. At first it was derided, but when it began to be confirmed by reality, by the "catalytic crises" of oil spills, smog in Los Angeles, and DDT in the rivers, then constituencies like the Sierra Club passed the book around and went into politics to throw out the polluters and elect legislators who passed laws and created, within just 10 to 12 years, new federal, state, and local environment agencies to manage the problems in an on-going way.

A similar sequence followed Ralph Nader's initiation of the safety and consumer movement with his Unsafe at Any Speed in 1965.2 And Paul Ehrlich's Zero Population Growth, ${ }^{3}$ which was a wild idea in 1968 , probably helped to raise consciousness and bring births below replacement level for the last three years by the free decision of tens of millions of couples. Likewise the 1972 book, Limits to Growth ${ }^{4}$ by Donella Meadows and co-workers, when reinforced by the reality of city problems and oil and energy crises, has led to new awareness and new laws across the nation and around the world within a very short time.

We see that the sequence of change, for causes that are moving with the tide of history, is very similar to that outlined by $\mathrm{Karl}$ Marx. It starts with analysis by the intellectual vanguard who have the knowledge and the leisure to do it, then it spreads by education of concerned people in small groups, until there is a confrontation with the system and a re-education of some members of the ruling classes, with a final takeover by the aroused public. The difference is that these fairly bloodless revolutions of attitudes and laws, in a high-education, high-communication society, now take only 13 to 10 years for social change instead of taking many decades, as workers' rebellions did a hundred years ago.

In fact, television may be a far more revolutionary force than newspapers or radio ever were, and we see these attitude-reversals now extending to other countries that have television. Birth rates are dropping to replacement levels or below in a dozen countries, there are startling changes in divorce and abortion laws in Italy, and in abortion and contraceptive laws in France. Our old ideas of "social lag", according to which 25 years is required for adjustment after a new technology comes in, have now been turned upside down. Now it is society that can turn around almost instantaneously, and technology that suddenly says "Don't rush us!"-for it will take 25 years to get better oral contraceptives, or mass transit, or coal gasification, or fusion power, or solar energy! But on the whole, this is a welcome change, for it means that we are becoming a cybernetic society, debating and choosing our values and which way we want to go, instead of having them forced on us by the technological juggernaut of self-interested inventors working for profits.

It is worth listing some of the areas where the attitudes, practices, or laws of decades or centuries past have been reversed since about 1968 , because it is often not realised how numerous these areas are. They include; detente between many countries, thus ending the Cold War; the new international money, Special Drawing Rights (since 1969), signalling that we are one world economically; the ecology movement; the changes in sex laws on homosexuality, porno- 
graphy, abortion, and contraception; birth rates below replacement level; a host of other legal changes towards less punishment and more official accountability, from the abolition of drunkenness as a crime to financial disclosure and election finance reform; the rights of students as adults in universities; increased employment of women and minorities; the pressure for reform in the churches (the greatest since the Reformation itself); and even widespread thinking about "The Year 2000", the farthest that the human race has ever looked ahead in this global way, with serious research and planning on how to get us there without destroying ourselves.

\section{The great world transformation}

These changes are, however, probably only the beginning of the great world transformation through which all countries will be passing in the next 20 years, if we survive. Unfortunately the strife between nations, between racial groups, and between religious groups, over some of these issues will be much less peaceful than these reform movements have recently been in a fairly wellintegrated nation like the USA. The next 10 years may be a decade of disasters as all the conflicts of resource sharing - what Garrett Hardin" has called "The Tragedy of the Commons"-become exacerbated between nation states claiming independent sovereignty. The probable disasters include: megafamines, with 50 million starving; oil wars; nuclear terrorism, with one or more new Hiroshimas; nuclear escalation between the super powers; economic collapse and depression; collapse of development hopes in poor countries; new racial or religious confrontations; and struggle for control of the multinational corporations. Or we can look, not at the crises, but at the overall problems of transition to a better-integrated global society in the next 20 years or so, a society able to forestall and manage these conflicts and crises before they destroy us. Broadly, there are five interacting problems of this kind, as identified by the transnational Club of Rome group: peace keeping; the rich-poor gap; resources and energy allocation; pollution control and ecological balance; and population levelling.

There are no priorities in this kind of list, because all these problems must be solved together to create a system that works. It is like the design of an automobile, where we must simultaneously design the engine, frame, transmission, wheels, steering, and brakes, and where a failure in any one ruins the system. So there must be 10000 sectors of our society that need to be worked on in parallel, all the way from individual awareness and family and neighbourhood relations, up to communities, schools, businesses, city councils, and state, regional, and national structures, and up to global problems, such as nuclear weapons, food and resources, and ocean pollution, that are too large and dangerous to be left to competing nation states.

"Civilisation is a race between education and catastrophe", H. G. Wells said, and one can see many of these constructive efforts to create new institutions to manage our problems coming to fruition in the next few years, being in fact catalysed by the crises, if the crises are not too huge or sudden. Such new institutions could include a world food stockpile and distribution system, an ocean management board, a world resources board, a nuclear control system 
capable of reducing the chances of terrorism, land reform and agricultural cooperatives in many countries, and new checks and balances on the multinational corporation, such as multinational labour unions, consumer groups, ecology groups, and anti-trust measures to block cartels.

One can already see global networks of tourism, technology, and television having more effect on the quality of our lives than decisions of the nation state, made in Washington or New York. The prosperity of American farmers depends on purchases in Moscow and Peking, oil and energy supplies on decisions in the Persian Gulf, automobile production on competition from Germany and Japan, and the import-export balance on decisions in Geneva and Paris. These networks of interdependence will probably go on growing in the next 20 years, so that the shape of the year 2000 may depend on the race between the crises, the networks, and the new institutions we set up to control them.

McGeorge Bundy, writing in the Saturday Review in August 1974, ${ }^{6}$ suggested that by 1989 our famines and nuclear terrorism might have led us to effective world covenants on peace keeping, food, and population, and to a great covenant that could be to the successful management of world problems what the US constitution was to the management of national problems 200 years ago. From the point of view of this time scale, which is consistent with the speed of change described here, the year 2000 is unpredictable in 1975, just as 200 years ago the year 1800 was unpredictable in 1775, with the French and American revolutions ahead; or 70 years ago, the year 1930 was unpredictable from the year 1905, with the growth of world communism and the overthrow of the monarchies of Europe through an almost unimaginable war. We are in a prerevolutionary era, and the shape of the year 2000 may be determined by accidents of assassination or the coincidence of several great crises, or conversely, by the hard work of groups at the neighbourhood level, or by some new philosophical restructuring, or by the inspired efforts of some leader at a crucial moment. We are on the knife-edge of history, a time as crucial as the Battle of Britain or Stalingrad and, depending on our efforts in the next few years, by 1989 we may have passed a point of no return, either toward human and humane survival or toward destruction. At this moment in history, the year 2000 is not to be predicted but to be created.

\section{What can women do?}

What has all this to do with women's roles? Everything. People cannot know what they must do unless they know where they stand and where they are likely to be going. In the total orchestration of things that need to be done to create a sustainable and satisfying society, there are thousands of areas where the vision and efforts of liberated women would be particularly effective or where, in fact, nothing can be done without them. No man should presume to give advice, because it is all too likely to be based on personal or outmoded stereotypes. Women should be in comparable numbers in every area of decision making, problem solving or institution building-if for nothing else, just to make sure that their interests, as half of the human race, are not being neglected or overridden. But if, as Judith Bardwick suggests, ${ }^{7}$ there may be some innate differences in male and female biopsychology, then probably women should 
get into some fields in more than equal numbers, to correct the distortions that men throughout history have imposed on our attitudes and our institutions. There is a general feeling now that the contribution of Western men has tended to be objective, technological, manipulative, concerned with things not people, with death rather than life, with thought rather than feeling, with punishment rather than positive reinforcement, with decision rather than ongoing assessment, with intervention rather than nurturance, and with closed control rather than with the natural and ecological rhythms of birth and death and open-ended growth. Men should correct such distortions in themselves, of course, but it would seem to be an area of world outlook where women at least may be less blinded by the past, and where they could be of enormous help.

And there are certainly some areas where the current roles, or the current rejections, of women-no matter how these roles or rejections may change in the liberated future-give them a better understanding of the problems than most men have. This may be true in such areas as the rights of minorities, distributive economic justice, the rights of patients and the dying; child-care centres, consumerism and product safety, ecology and pollution control; new family and neighbourhood structures; the rights concerning privacy, advertising, television and the media, health insurance, the rights of the old; part-time and flexible working hours, the use of leisure, religious reform, education throughout life; world famine, and food and distribution; population, health care and development in the poorer countries, and peace keeping. The dream of the suffragettes and of the League of Women Voters is still ahead-that liberated women can become a far more powerful force in politics and social change than they have ever been. People will have first to get it all together at the personal and psychological level of daily life, of course, but once that is done, what a powerhouse! Personal awareness will begin to create and support healthier national and international structures at every level, and healthier large-scale structures for survival will in turn begin to support personal awareness and growth for millions and billions.

\section{What about the family?}

There is a need for analysis and effort and new institutional design, as can be readily seen by examining the structure of the family. This is an area where men and women both must contribute, but it is an area which is absolutely central for the straightening out of women's personal problems, their daily lives, and the equality of their roles. If the family is not working right for women, nothing else can be made to work right.

I would claim that the nuclear family today is generally not working right for anybody over the whole life span. Those young adults in the 1920 s who moved into the small flat or suburban house far from relatives and grandparents, created a monoculture of a single age group, with whole blocks and whole surburbs aged 30 to 35 and with children aged 5 to 8 , all growing older together. This separation of nuclear families on a mass scale was, I believe, something fairly new in history. It was a response to the rapid change of values that came 
with science, electric lights, telephones and motor cars, and with Darwin and Pasteur, and it reacted back in turn, and helped to change the values still more rapidly.

But its longer psychological effects over the last 50 years have been damaging to every group involved. The parents in the two-adult family are forced into more roles than they enjoy, or know how to play. The wife, for example, has to be a cook, maid, baby sitter, educator, purchasing agent, chauffeur, business manager, fun person, analyst, hostess, and good in bed. An extended family had teenagers and aunts and uncles to share some of these jobs. Likewise, the children in the nuclear family have no teenagers around to help the brunt of parental pressures, no aunts for consolation, and they are boxed in with their peer group and the television set. And when they grow up and leave home, the old people are left with the big empty nest with no one to help, and finally must go off to the trailer camp, the Sunset Colony, or the old folks' home.

This is no way to live! Whatever genetic or cultural inheritance we have, it was almost certainly not designed for this kind of one-couple age-group isolation. We are not solitary carnivores, but primates, who live in groups and talk together. No wonder the alcoholism and divorce rates are so high! And the worst thing about the nuclear family is that its support breaks down at just the moments of illness or separation or death, when we need a family most, and when it is too late to set up the broader relationships that could have helped us. It is both an inadequate structure in itself, and a dangerously misleading image for advertisers, business men and officials, who do their planning and selling around nuclear families when half of all Americans: students, singles, broken families, and the old, do not live in that pattern.

What shall we put in its place, and how shall we create it? We need something that combines the real values of the nuclear family-openness to change, mobility for those who wish it, independence from authoritarian grandparents-with a broader supporting fellowship and help in times of stress throughout the full length of life. Many people recognise the need for more open and embracing relationships, and this is why there are now an estimated 2000 communes in the USA with some 40000 members, with the numbers in the summer perhaps becoming as great as in the communal kibbutzim of Israel. They are not all Californian hippies in the mountains, but the number includes religious and pacifist groups in many cities, and well-off advertising men and women who have organised family clusters in six-flat buildings in New Jersey, as well as $\mathrm{PhD}$ ecologists running demonstration farms with "alternative technology".

The trouble is that the failure rate in these "intentional communities" is extremely high-even higher than in marriage-with enormous losses in money and effort, and disappointment and bitterness. There are problems much like those that broke up the non-religious communal experiments of the 19 th century, problems of leadership and transfer, sexual jealousies, decision making, financial management, uncooperative members, and the hostility of the surrounding community. Is it so impossible to put our brains to work on some of these problems, so as to show groups how to use many of the things we have learned today and small-group behaviour, participatory management, or positive reinforcement to help each other toward mutual goals?--so that these groups might begin to have examples and images of better problem solving, 
or so that they might have the security and stability of, say, a small kibbutz or, at least, of the average marriage?

Sociology or psychology departments concerned with new structures for more liberated women might have a big impact by calling a conference on extended families, where architects, lawyers, economists, psychologists, and child-care people could meet ecology groups, church groups, neighbourhood groups, or others interested in undertaking such experimental communities. The architects could show how to combine community space with privacy; the lawyers could examine neighbourhood relations and rights, contracts and equity, and child-care commitments if parents separated; the economists could examine the costs and benefits of living in a group, the balance between inside and outside work, and how to spread benefits fairly; and the psychologists could show how to apply new management methods and reinforcements to more satisfying problem solving or group child care. There are many of these areas where different experimental communities might try different sets of rules, so that after a year or two some useful handbooks of guidance would be available for thousands of city, or rural, or religious extended-family groups.

This is the kind of catalytic analysis that brings our new knowledge to bear on improving our most fundamental institutions when they have begun to damage the possibility of both being free and independent and yet being mutually sharing and supporting. What other sociological study could have nearly so high a priority? And any successes along these lines might be of great value not only for groups in the USA but also in suggesting to other cultures how they might modernise toward more equality for women without having to go through our catastrophic experience of the nuclear family, which some of them are now trying to imitate.

Most men would rejoice if women came to play their full role in a thousand problems of this kind, where we need to bring together our full intelligence and social knowledge, our full biological and emotional understanding, and our humane values, to create the new institutions which we will need to keep us fully sane and fully human in that new world ahead. It would liberate the men as well as the women, and the old people and children too, not into the liberation of isolation, but into the liberation of full and equal relationships.

\section{References}

1. Rachel Carson, Silent Spring (Boston, Houghton Mifflin, 1962).

2. Ralph Nader, Unsafe at any Speed (New York, Grossman, 1965).

3. Paul Ehrlich, The Population Bomb (New York, Sierra Club, 1968).

4. Donella H. Meadows, Dennis L. Meadows, Jørgen Randers and William W. Behrens III, The Limits to Growth (New York, Universe Books, and London, Earth Island, 1972).

5. Garrett Hardin, "The Tragedy of the Commons", Science, 162, 13 December 1968, pages 1243-1248.

6. McGeorge Bundy, "After the Deluge, the Covenant", Saturday Review World, 24 August 1974, pages 18-20, 112, 114.

7. Judith Bardwick, "The Great Revolution", University of Michigan Conference on "New Research in Women", 19 March 1975. 